\title{
'I'm not sure how to begin it': The Welcome Uncertainties of Doing History
}

\section{Tony Birch}

\section{[White] Possession}

If you don't mind I'd like to begin with a question. Does anyone remember the 'History War' of the late nineties and early years of the new century? Yes, I'm sure some of you do. Okay. Next question. How many of you remember who volunteered for the frontline in this war? I hope you don't mind if I also speculate a general response:

The History War in Australia was a battle between conservative forces, led by the then prime minister, John Howard, and his hardened foot soldiers such as the writer, Keith Windschuttle, supported by the armoured carrier, Quadrant magazine. On the other side of the trenches were Aboriginal people, outgunned and unable to fight for themselves. They came to rely on a band of mercenaries known collectively as the professional historians. And what was the war fought over? Well, it's a little complicated, but let's throw a net over this one and address Australia's colonial past and the reverberation of that past in contemporary society.

The answer to the second question is reasonably accurate, although it lacks specific detail. Unfortunately the answer to the first question is an act of camouflage. We all remember Keith Windschuttle as a suitable rightwing whipping boy for the Left. He was the Snidely Whiplash in a pantomime of smoke and mirrors. And John Howard? For sure, he had the clear intention in mind of shifting public debate in Australia, away from what he regarded as the unnecessary depth of the 
mea culpa expressed by the then prime minister, Paul Keating, in his 1992 Redfern speech. In 1996 Howard produced an oration of his own when delivering the annual Thomas Playford Lecture in Adelaide. It was on that night that Howard attempted to take Australia back to the 1950s, presenting the view that Australians were entitled to hold a 'relaxed and comfortable' view of Australian history.

The History War was actually a turf war, waged between liberals and conservatives over who would control the discipline. Those on the Right were concerned that a dominant narrative doing the rounds at the time was sympathetic to Aboriginal people. Not only was control of the past at stake but land and the potential for reciprocity over past wrongs. When the Human Rights and Equal Opportunity Commission (HREOC) released its Bringing Them Home report in 1997, dealing with the history and legacy of the removal of Aboriginal and Torres Strait Islander children from their families and communities, Australians were faced with sharp choices and important questions. ${ }^{1}$

Did Australia possess the maturity to express genuine remorse for this violent and destructive history? I have no doubt that some white Australians did feel remorse. Whether it was a lasting expression is difficult to assess, although I suspect that with time, that remorse dissipated. Also, while many thousands of people registered testimonials in Sorry Books across the nation, and hundreds of thousands more marched in our major cities in 2000 in support of reconciliation, these acts of symbolism, on their own, rung hollow.

Beyond acts of symbolism and self-satisfaction it is inarguable that white Australia is capable of fully accepting responsibility for past wrongs against Aboriginal people. On this point the political and legal systems, along with the wider community, has failed miserably. The stories provided to the Bringing Them Home inquiry were heart-wrenching. A close friend of mine returned home to South Australia and, along with other women, gave her own testimony in-camera. The nature of the stories presented were so harrowing they were not released to the public. When the Bringing Them Home report was released to the public many non-Aboriginal people were 
in tears, including the then opposition leader, Kim Beazley, who broke down in parliament. I have previously written that I have no doubt that the expression of grief by Beazley and others was genuine. Unfortunately, at the same time, many of those who broke down held the same view as conservatives, that Aboriginal people should not be entitled to compensation as a result of the crimes committed against them.

It's not about money, we heard many people comment at the time. An odd remark, in a country where people have the democratic and legal right to seek recompense in the civil court for pain and suffering. And after all, at the time and since, many people have rightly received monetary compensation for the abuse they suffered as children while in both government and privately operated institutions. (In most cases, victims have received monetary compensation without the trauma of a court case.) So, where's the connection? Well, firstly, and let's dispose of this quickly, I have no doubt that those who opposed the notion of monetary compensation for Aboriginal people held to the racist viewpoint that Aboriginal people do not have the level of sophistication to handle money of the amounts suggested. Also, in seeking compensation it was as if Aboriginal people were spoiling the purity of white grief.

There is nothing revelatory about this view. And nothing new. But what compensation would have resulted in was an outcome. Genuine reciprocity has the potential to produce a state of equity. And the last thing many Australians desire or can cope with is for Aboriginal people to experience a state of equity. Many wish to maintain the inequitable and patronising relationship of pity. It is the emotion that drives the relationship between conservative and liberal-minded Australians alike in their dealings with Aboriginal people. The reception of the Bringing Them Home report upheld this perverse notion. People could feel and express their sadness. They could take on Aboriginal grief as their own. And they could feel the 'sorrow and the pity' for those who had suffered with no cost.

Is this a harsh - even cruel - judgement on my part? Possibly. But not nearly as cruel as the outcome for the Aboriginal people who relived the horrors of their experience 
at the Bringing Them Home hearings. And not nearly as cruel as the burden of national collective memory carried by Aboriginal people from childhood, through adulthood, often separated from family, to the grave. I know many Aboriginal Elders, most of them women, who can never afford to forget this past, even though they would occasionally prefer to, if for the briefest moment of relief. Is this not the most savage and violent irony in a country otherwise glued together by selective and collective amnesia? Collective responsibility lies within each of us. And yet we have failed miserably in applying it. Marching across the bridges of reconciliation was not an act of responsibility. It was an expression of self-congratulation. And, bizarrely, it had the effect of delivering Howard's 'relaxed and comfortable' mantra to the masses, with people going home at the end of the day carrying balloons and feeling good about themselves.

The second choice that Australian had available to them after the release of the Bringing Home Report was to deny its contents completely. The testimony and resulting report was another fiction, a lie concocted to sully Australia's colonial past; a story of the progress of European civilisation and capitalist development and growth across a wide brown land. Some Australians took up the denialist mantra with inherent ease. Others needed a little nudging and leadership. This is where conservatives came into their own, defending 'ordinary Australians' who had nothing be ashamed about, people who were entitled to express pride about Australian history, people who need not cover the monuments of the nation in black cloth. This was John Howard at his best (and worst). Who better to lead a throwback narrative of the nation's story than a strategically astute throwback? We could feel pity for those we had 'conquered' with a clear sense of 'relaxation'.

There was, of course, for the mining and agriculture sector, big business and conservatives, something more immediately at stake: land. The various legal manifestations of the native title legislation that followed the High Court's Mabo decision in 1992, while offering very limited outcomes for Aboriginal people, did send fear through those who hold a short term and exploitative philosophy of land tenure. (Certainly, many exploited unrealised fears.) The debates over history were 
more immediate with regard to native title specifically and land rights more generally. These were debates over the past that held the potential to be decided in the court. Pity and sorrow would play little part. These would be more hard-nosed debates, where proof and evidence would come into play. Hence the privileging of the footnote and the arrival of the professional historian.

The History War was a white war. It was a battle over control of a discipline. On one side were a group of populist mavericks who behaved crudely on occasion. While feigning the manners of the formal discipline of history, they didn't exactly abide by the Marquis of Queensberry rules established by the dons safely embedded behind the sandstone fortresses of Australia's older universities. Opposing them were the aristocrats of the discipline, disgusted that their lifework was being pissed on by a troupe of populist yobbos faking intellectualism. Aboriginal people were regarded as nothing more than a carcass of history. Rather than being the body protected by the history profession, we were picked over by opposing sides. Whoever won the battle would take what was left of the carcass home, back to the ivory tower, gentlemen's club or museum glass case, to be paraded like the colonial trophies of old.

The History War allowed some Australians to seep themselves in sepia. Many did, unfortunately. With hope in mind, this period in Australia's intellectual life (or lack of it), also provided those interested in a more sophisticated articulation of Australia's past with the opportunity to produce new narratives, based on ethical thinking, experimentation and humility. Thankfully, some of these ways of seeing and writing were able to cut through the bullshit, and they subsequently had a welcome and profound impact on my own thinking. I, $w e$, are indebted to these writers.

\section{[White] Dispossession}

UTS Review and its reincarnation, Cultural Studies Review, has always done the thinking and writing about history a little differently; no doubt influenced by the fact that many of the writers appearing in the journal who have tussled or danced with history are not members of the professional historian's 
club. They are a suspect bunch. If not Edward Said's amateurs, they have been, at a minimum, meddling polymorphic intellectuals stepping outside their own discipline with the audacious idea that they have something to say about history. During the History War, cultural studies types were whipped around the ears with a feather by liberal-minded aristocrats as often as conservative historians were. And they were perhaps more dangerous. Looking back over some of the work published in the last twenty years or so by the journal it is important to remind ourselves that the ways in which we remember, document and deal with the past in Australia has been articulated with creative and intellectual ingenuity by particular thinkers.

Writing for UTS Review in 2001, Wendy Brady rightly took on those intellectuals who, armed with the undoubted confidence in their sense of entitlement, felt that they could write about whoever they wished and when. The Aboriginal Other of the 1990 s were regarded as a troublesome nuisance when it came to matters academic. We were, to the greater extent, well outside the tent. And when we did enter we behaved badly, demanding the right to speak for ourselves, and occasionally asking those who could talk under academic wet cement to shut up. It was not uncommon to go to conferences when all the speakers on a panel talking about the aborigines were non-Aboriginal, as were most members of the audience. When an Aboriginal hand went up, anytime a blackfella got to her feet demanding to be heard, audience members would sink into their seats, while those behind the microphones would offer a half-arsed apology or defence. Afterwards, over the tea and biscuits (which were never good) the quiet collective mutterings about 'the rudeness of those people' would build to a crescendo of hysteria. (I kid you not, I was there).

Brady's essay, 'Indigenous Insurgency Against The Speaking For Others', ${ }^{2}$ was written at a time when prominent historians, including Henry Reynolds, Ann McGrath and Bain Attwood, had been anointed as the most highly regarded experts on Aboriginal history. It should go without saying that each of these historians had done and continue to produce significant and influential scholarship. And yet among scholars involved in the debate about Australia's past there were 
no Aboriginal voices beyond the token warm-up act before a conference, forever welcoming people to country, or an 'open mic' at the end of a conference session. Reading Brady's essay years later I still sense her anger and frustration. Importantly, she does not only demand that Aboriginal people be given the respect and space to speak for ourselves. She also pleads with non-Aboriginal scholars to give some thought to doing things differently.

And perhaps with a combination of humility and creativity? Enter one Stephen Muecke. Muecke had caused much excitement among scholars following the co-authorship of Reading the Country with Aboriginal Elder, Paddy Roe, and the artist, Krim Benterrak, in $1984 .{ }^{3}$ The project was genuinely democratic, patient and captivating. The book was also a milestone in Muecke's intellectual development. The time he spent with Paddy Roe and his community exposed Muecke to an Aboriginal way of making sense of the world - an Aboriginal philosophy - and freed him of the restraints of academic thinking without having to forgo the institution completely. His 1996 essay was an exercise in giving up the traditional authority of the Western academic, and if not fully satisfying Brady's call to stepping out of the way, it at least met with her desire for non-Aboriginal intellectuals to reconsider their position of privilege. ${ }^{4}$ Muecke's experiment was not so radical on face value. He was, as he put it, asking us to think differently about how we engage with the past, to challenge traditional modes of research and narrative documentation, and, as he put it, to test things out (Muecke's italics). He did not want to turn the academic house upside down, aware of the potential 'irresponsibility' of such an act. But he did want to shake it up.

With the exception of a handful of young historians who had enjoyed the pleasure of sitting at the mischievous table of the late and great Professor Greg Dening, few took up Muecke's lead or challenge. Muecke simply shrugged his nonchalant shoulders and ploughed on, becoming simultaneously an intellectual trickster and a deeply moral thinker. His 2008 Cultural Studies Review essay was a timely reminder of the value of his project and the potential of its objective. ${ }^{5}$ Rather than narrowly viewing Captain James Cook 
as an imperial hero, Muecke's idea (shared with the scholars Chris Healy and Katrina Schlunke) was to engage with Cook as 'an enduring icon, a huge network of narratives, images and ceremonies'. There was no disrespect sought in such an approach. Taking his lead from Aboriginal narratives of Cook, Muecke explained that the "new chapters on Aboriginal history to the Australian story has not had the effect of wiping out Captain Cook, it has simply added something compelling as a story and as an argument'. ${ }^{6}$

Another innovative scholar appearing in the journal around the same time was the respected historian, Heather Goodall. Goodall cut her political and intellectual teeth in the urban land rights protest scene of the early 1970s. Her pathway to intellectual thought was, not surprisingly, like Muecke's heavily influenced by regular socialisation with Aboriginal people. She did not become involved with Aboriginal people to study us. Her involvement, I suspect, was an act of political urgency mixed with the determination of being a young activist. While political activism is a hard and sometimes unrewarding slog, the education and insight it provides cannot be found in any textbook. Knowledge is experienced through both the heart and the head. It is at times a visceral experience. Those who go through it, and learn from it, not only challenge their own thinking. They often become the mentors to those who decide to follow in their footsteps.

It is not surprising then that the echoes of Goodall's UTS Review essay can be found in a later Cultural Studies Review essay by Eve Vincent. 7 The Goodall essay, similar to Muecke's work, was another attempt at inclusion. Through a discussion of storytelling and how it operates in rural communities, Goodall provided an insight into the complexity of narrative, politics and memory when Aboriginal and non-Aboriginal people compete over the same land. With oral documentation taking on greater significance as one outcome of native title legislation, Goodall was aware of the ramifications for the privileging of particular stories over others. The essay is a sad one, in that, purposefully or not, it highlights some of the commonalities of experience shared by Aboriginal and nonAboriginal people in rural and regional Australia: experiences of loss and disadvantage. They are often the people city-based 
politicians use as a wedge to enhance their own political standing.

Eve Vincent, now an anthropologist, tells the story of her travels to Coober Pedy and her meetings with the Aboriginal women of the Kupa Piti Kungka Tjuta (a council of senior Aboriginal women based in Coober Pedy). It is a piece of writing immersed in respect and necessary self-reflection and examination. My response to reading the article may sound a little hippy. Please don't be mistaken. Vincent begins her essay with the honest assessment, 'I'm not sure how to begin it.' (And maybe she doesn't). But what she does know is that she must tread a little lightly on land that does not belong to her. And what she also knows is that the Aboriginal women she engages with are running the show, and that if her trip and subsequent 'research outcomes' are to meet with success, she must listen to, observe and learn from these women. I have no idea if Vincent was aware of these ethical and intellectual guiding stars before embarking on her trips to outback South Australia. Or if she discovered them as an act of doing. (I suspect it would most likely be a bit both, with an emphasis on the latter.) The essay is a quiet, observational cameo, which befits a scholar never ashamed to admit she doesn't know it all.

Vincent's work, along with the scholarship delivered by Muecke, Goodall and other non-Aboriginal scholars has often delivered me a sense of hope. They are writers and thinkers dissatisfied with a pervading sense of the colonial status quo that some in Australia desperately cling to. But the inroads of such thinkers are sadly limited. The project of shallow nationalism and petty hero worship is hard to shift in this country. (The current commemorations of the one hundredth anniversary of the beginning of World War I are indicative of this eternal flag-waving exercise.) And all the while that we remember a war on the other side of the planet, we continue to go to war at home against some of our own citizens. Recent revelations that the New South Wales police removed Aboriginal children from their homes in riot gear and at gunpoint is indicative of wider and systemic practices of a twenty-first-century manifestation of colonial violence. ${ }^{8}$

With this in mind, Irene Watson's analysis of the Commonwealth government's state intervention in the 
Northern Territory in 2009 was a reminder that despite the rhetoric of progress with which the nation dresses itself, many Aboriginal people continue to live in circumstances approaching a police state. 9 She correctly likens the use of the military by the Commonwealth to occupy Aboriginal land as an act of state aggression and desperation. Watson reminded us that government strategies to deal with issues of poverty, an absence of a functioning education and heath system, and the related problems of abuse and domestic violence, were only made possible by removing rights from Aboriginal women. Her assessment that the Northern Territory intervention 'is more a comment upon the Australian government's management of the colonial project than it is about the culture of perpetrators' is a damning and accurate conclusion to one of the most articulate, informed and powerful pieces of writing produced around state policy and Aboriginal communities in the twenty-first century. ${ }^{10}$

From its beginnings, UTS Review and Cultural Studies Review has attempted to shift debate in Australia with vigour, cheek and boldness. Without the interjection of the journal into Australian intellectual life, and its analysis and commentary on the history and culture of this country, we would have asked far fewer questions of ourselves. And we don't like asking questions in this country, particularly when we feel unease over the answers. But what we need, now more than ever, is unease and discomfort, rather than the opposite. To make this possible we require the shape-shifting provocations presented by writers such as those I have mentioned.

\section{Notes}

1 Human Rights and Equal Opportunity Commission (HREOC), Bringing Them Home: A Report of the National Inquiry into the Separation of Aboriginal and Torres Strait Islander Children from their Families, Human Rights and Equal Opportunity Commission, Sydney, 1997.

2 Wendy Brady, 'Indigenous Insurgency Against the Speaking for Others', in this volume, pp. 112-21.

3 Krim Benterrak, Stephen Muecke and Paddy Roe, Reading the Country: An Introduction to Nomadology, Fremantle Arts Centre Press, Fremantle, 1984.

4 Stephen Muecke, 'Experimental History? The "Space” of History in Recent Histories of Kimberley Colonialism', in this volume, pp. 50-63.

5 Stephen Muecke, 'A Touching and Contagious Captain Cook: Thinking History through Things', in this volume, pp. 153-66. 
6 Ibid., pp.157.

7 Heather Goodall, "Fixing” The Past: Modernity, Tradition and Memory in Rural Australia', in this volume, pp. 91-111; Eve Vincent, 'Knowing the Country', in this volume, pp. 138-52.

8 See, 'Police in riot gear removing Aboriginal children at "gunpoint"', http://www.sbs.com.au/news/article/2014/o9/12/ police-riot-gear-removing-aboriginal-children-gunpoint.

9 Irene Watson, 'In the Northern Territory Intervention: What is Saved or Rescued and at What Cost?', in this volume, pp. 167-85.

10 Ibid., p. 181. 